\section{Identification of D-Aspartic Acid and D-Glutamic Acid in Pea Seedlings}

\author{
Tadashi Ogawa, Masumi Kimoto \\ and Kei SASAOKA \\ Department of Nutrition, School of Medicine, \\ Tokushima University, Tokushima, Japan
}

Received May 26, 1977

In previous studies, ${ }^{1 \sim 3)}$ free D-alanine and its conjugates, $N$-malonyl-D-alanine and $\gamma$-Lglutamyl-D-alanine, were identified in pea seedlings. The total D-alanine content increased during germination and amounted to $3 \mu$ moles per seedling at 8 days. $^{3 \text { ) }}$ In addition to D-alanine and its derivatives, the authors found a wide distribution of ninhydrin negative conjugates of $\mathrm{D}$ - $\alpha$-amino- $n$-butyric acid in legume seedlings. ${ }^{4}$ ?

For the determination of the D-amino acids, D-amino acid oxidase was conventionally used. But, on account of the substrate specificity of this enzyme, the optical configuration of several amino acids such as aspartic acid and glutamic acid can not be identified, though the presence of the D-isomers of these amino acids has been expected since the discovery of D-amino acid aminotransferase in pea seedlings. ${ }^{5)}$ The present work was carried out to examine the above possibility by using of the method of Manning and Moore. ${ }^{6}{ }^{\prime}$

Free aspartic acid and glutamic acid in 7day-old pea seedlings were isolated chromatographically by the use of Amberlite CG-120 (pyridinium form, $1.5 \times 90 \mathrm{~cm}$; eluent, $0.1 \mathrm{M}$ pyridine-formic acid, $\mathrm{pH} 3.1$ ). These amino acids also occurred as ninhydrin negative conjugates $^{7)}$ in the anionic fraction* of pea seedlings. Both the amino acids in this fraction were isolated by the same chromatographic procedure after hydrolysis $(6 \mathrm{~N} \mathrm{HCl}$, $105^{\circ} \mathrm{C}$ for $20 \mathrm{hr}$ ). The identity and purity of the amino acids isolated were confirmed by

* Not adsorbed by Amberlite IR-120B $\left(\mathrm{H}^{+}\right)$and adsorbed by Dowex $1 \times 4$ (Acetate). two dimendional paper chromatography and by the automatic amino acid analyzer. ${ }^{7}$

Definite amounts of the amino acids isolated as free and from the hydrolyzate $(0.1 \sim 0.5$ $\mu$ mole) were dissolved in $2 \mathrm{ml}$ of $0.4 \mathrm{M}$ sodium borate buffer, $\mathrm{pH} 10.2$ and were treated with L-leucine $N$-carboxyanhydride at $0^{\circ} \mathrm{C}$ for $2 \mathrm{~min}$ under vigorous agitation. The resulting $\mathrm{L}-$ leucyl dipeptides were subjected to chromatographic separation with an automatic amino acid analyzer (Yanagimoto LC-5S), and the chromatograms obtained are shown in Fig. 1.

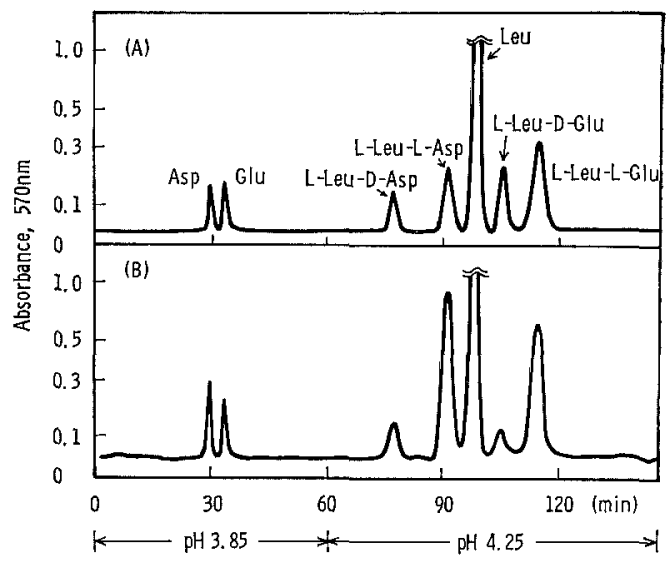

FIG. 1. Chromatographic Separation of the Isomers of Aspartic Acid and Glutamic Acid.

Chromatographic conditions: Bio-Rad Aminex A$4(0.9 \times 90 \mathrm{~cm})$; sodium citrate buffer, $0.2 \mathrm{M}, \mathrm{pH}$ 3.85 and $4.25 ; 52^{\circ} \mathrm{C}$; flow rate, $80 \mathrm{ml}$ per hr. Color yields of authentic materials relative to leucine $(1.00)$ were as follows: L-Leu-D-Asp, 0.54; L-Leu-L-Asp, 0.73 ; L-Leu-D-Glu, 0.61 ; L-Leu-L-Glu, 0.78 .

A. Authentic materials. B. A representative chromatogram of L-leucyl dipeptides of aspartic acid and glutamic acid isolated (hydrolyzate of the anionic fraction of pea seedlings).

TABLE I. CONTENTS OF THE OPtical IsOMERS of Aspartic AcId and Glutamic Acid IN Pea Seedlings

\begin{tabular}{lcccc}
\hline $\begin{array}{l}\text { Optical } \\
\text { isomer }\end{array}$ & \multicolumn{2}{c}{ Free form } & \multicolumn{2}{c}{ Conjugated form } \\
\hline & $\begin{array}{c}\mu \text { mole/ } \\
\text { seedling }\end{array}$ & $\%$ & $\begin{array}{c}\mu \text { mole/ } \\
\text { seedling }\end{array}$ & $\%$ \\
D-Asp & 0.221 & 10.2 & 0.119 & 13.4 \\
L-Asp & 1.945 & 89.8 & 0.768 & 86.6 \\
D-Glu & 0.283 & 7.9 & 0.191 & 12.3 \\
L-Glu & 3.928 & 92.1 & 1.368 & 87.7 \\
\hline
\end{tabular}


The contents of the optical isomers calculated from the chromatogram by the method of Manning and Moore, ${ }^{6)}$ are summarized in Table I. Approximately $10 \%$ of both the amino acids in the free and conjugated forms was proved to have D-configuration by this experiment. Racemization of these amino acids during the isolation process did not occur and that by hydrolysis of the anionic fraction did not exceed $2 \%$. These facts evidently indicate that pea seedlings contain the D-isomers of aspartic acid and glutamic acid together with $\mathrm{D}$-alanine, $\mathrm{D}$ - $\alpha$-amino- $n$ butyric acid and D-phenylalanine which was proved to exist as the $N$-malonyl conjugate by gas chromatographic and mass spectrometric analyses (unpublished, T. Ogawa and K. Sasaoka). D-Aspartic acid and D-glutamic acid were known to be common constituents of bacterial cell walls ${ }^{87}$ and D-aspartic acid was also found in a seaweed. ${ }^{97}$ But, this is the first report on the natural occurrence of Daspartic acid and D-glutamic acid in higher plants.

\section{REFERENCES}

1) T. Ogawa, M. Fukuda and K. Sasaoka, Biochim. Biophys. Acta, 297, 60 (1973).

2) M. Fukuda, T. Ogawa and K. Sasaoka, ibid, 304, 363 (1973).

3) M. Fukuda, A. Tokumura, T. Ogawa and K. Sasaoka, Phytochemistry, 12, 2593 (1973).

4) T. Ogawa, N. Bando and K. Sasaoka, Agric. Biol. Chem., 40, 1661 (1976).

5) T. Ogawa, M. Fukuda and K. Sasaoka, Biochem. Biophys. Res. Commun., 52, 998 (1973).

6) J. M. Manning and S. Moore, J. Biol. Chem., 243, 5591 (1968).

7) K. Sasaoka, T. Ogawa and M. Fukuda, Agric. Biol. Chem., 36, 383 (1972).

8) K. H. Schleifer and O. Kandler, Bacteriol. Rev., 36, 407 (1972).

9) K. Daigo, Yakugaku Zasshi, 79, 365 (1959). 